\title{
Representation of Gender Inequality in Indonesian Vocabulary
}

\author{
Ribut Wahyu Eriyanti \\ University of Muhammadiyah Malang \\ eriyanti@umm.ac.id
}

\begin{abstract}
Language as a sign contains elements outside the language, i.e. culture, thought, ethnic behavior of the language owner. The patriarchal culture of Indonesian society is also represented in Bahasa Indonesia. This paper aims to explain the representation of gender inequality in Indonesian words. For that reason, the exploration and analysis of Indonesian vocabulary in the literature and in oral communication activities are conducted. Based on data analysis, gender inequality is represented in Indonesian vocabulary in the form of (1) marginalization dignity of woman compared to man, (2) subordination of woman to a man, and (3) woman as professional marker.
\end{abstract}

Keywords: representation, Indonesian language, gender inequality, vocabulary

\section{INTRODUCTION}

Language as a sign has two sides, a signifier and signified. Saussure (in Wareing, 1999) states that each sign has two sides, a signifier of a "label" and a signified, which is a concept or meaning. The sign represents a composite of both. In the language, signified and signified correspondence is a unified whole. The act of presenting something through something else outside of itself (usually a sign or symbol) is called a representation [1].

A proverbial "Language Indicates the Nation", has long been known in the community. The proverbial implies the meaning that language contains elements outside the language, i.e. culture, thoughts, customs, and ethnic behavior of the language owner. Moreover, there is a reciprocal relationship between language, thought, customs, and ethnic behavior of the language owner. Culture cannot develop without language and vice versa.

The Sapir-Whorf Hypothesis (in Wareing, 1999) states that every culture interprets the world in different ways. The difference is encoded using language. For example, some cultures perceive all types of rice and rice product in the same name, rice. However, Indonesian people differentiate various types of rice to be processed into food by giving different names, such as padi (rice that is still in the rice plant), beras (rice that is peeled from its husk), nasi (cooked rice), lontong (cooked rice which is wrapped by banana leaves) and others. There is no absolute ordinance to be the same to label the contents of this world. Someone gives the label or name everything in this world according to their own perceptions. These perceptions are relative and different according to their culture. That's called language relativity.

On the other hand, Sapir [2] states that it is not only human perceptions of the world that affect language, but the language used can also influence the way people think deeply. According to him, once a language system is formed, the language will affect the way members of the community discuss and interpret their world. That is the principle of Language determinism.

Accordingly, Cavallaro [1] argues that the effort to understand the representation of language should be based on the understanding that the world cannot be represented accurately and objectively because the world is not something given but the effect of how the world is understood from various points of view. Based on this, an understanding of the representation of gender injustice in the Indonesian vocabulary should be done in relation to the social context. It is in accord with Volosinov's view that all signs are social, including language, born of social interaction in which language users.

Indonesian language was created and used by the people of Indonesia. Characteristics of patriarchal Indonesian society is reflected in Bahasa Indonesia. It canbe seen in some Indonesian vocabulary that shows the difference of men and women unequally. The word "wartawan" (journalist) in Indonesian refers to all generic professions, both male and female. On the other hand, there is the word "wartawati" who marks the female gender journalist. Meanwhile, to mark the male genital reporters still used the word "journalist". Based on that conditions, this paper discuss the forms of gender inequality that is represented into Indonesian vocabulary.

\section{METHOD}

The purpose of this study is to explain the forms of gender inequality that are represented in Indonesian vocabulary. Therefore, qualitative phenomenological research method is used. The research data is obtained through observation of Indonesian usage in oral communication and written in electronic mass media, print, book, and language event in society in formal and informal situation. Researchers act as research instruments assisted by data recording devices. Data analysis was performed during data collection and also after the data were collected. 


\section{RESULTS AND DISCUSSION}

Forms of Gender Inequality in Indonesian Vocabulary. The problem reviewed in this study are forms of gender inequality in Indonesian vocabulary. A strict distinction between men and women creates injustice for both men and women. This injustice is known as gender injustice. Based on these limitations, the result of data analysis found that there are three forms of gender injustice represented in Indonesian vocabulary, (1) marginalization, (2) subordination, and (3) professional marker. Representation of Female Marginalization in Indonesian Vocabulary. Marginalization is a condition or process of lowering of one sex from the mainstream / work which results in poverty. For example, technological developments cause what was originally done manually by women taken over by machines that are generally done by men. It is represented in Table 1.

Table1: Representation Data of Women Marginalization in Indonesian Vocabulary

\begin{tabular}{ll}
\hline No General & man woman \\
\hline & Tuna susila - wanita tunassusila \\
& Wanita penghibur - wanita penghibur \\
& Wanita panggilan - wanita panggilan \\
\hline
\end{tabular}

The vocabulary in Table 1 represents that women are in marginal positions. The use of the word woman in those words tends to have a negative connotative meaning. The word "woman" is often used in usage contexts that cannot be replaced with the word "man" and tend to lead to negative connotations. It does not exist in men, although there are also men who have the same behavior as that of women.

It represents gender injustice in the Indonesian language. Certain words or terms are used to label the behavior of women who are perceived to be distorted, even if the behavior occurs because of the behavior of men who also deviate. However, negative labels are only imposed on women, while men who are also experiencing the same thing do not get a negative label.

Before the issue of gender was raised, Noerhadi (in Santoso, 2006) argued that the Indonesian people are accustomed to thinking in imaging. Based on that, in societies it evolves the myth that women are perceived as weak creatures who have to be loved, protected, and lauded. Such views are embedded in society not only because of men view, but women also admit it. Such a thing is reflected in the use of language.

Similarly, [3] points out that the use of genderdifferentiated languages has a significant role in the marginalization of women in various professions, especially career advancement and development. Graddol (1989) also argues that language does not merely serve as a reflection of society, but is also applied strongly in the construction and preservation of social and inequality roles division.
Representation of Women's Subordination in Indonesian Vocabulary

Subordination, i.e. one of the sexes is deemed lower or subordinated to its position compared to the other sex. For example, because women give birth and breastfeed children, it is the task of parenting, cooking, and taking care of other domestic sector, while men are in the public sector. Based on these limitations, the results of data analysis indicate a form of female subordination in Indonesian vocabulary. It is represented in Table 2.

Table 2: Subordination Representation of Women in Indonesian Vocabulary

\begin{tabular}{ll}
\hline No General & Man woman \\
\hline 4 & Dharma wanita \\
5 & Wanita Karir \\
6 & Ibu rumah tangga \\
\hline
\end{tabular}

The word "dharma wanita" has the connotation of the meaning that women are in charge of serving men (as husbands) to support the work of men (as husbands), so women (as wives) must actively engage themselves in the men's (husband's) workplace without being rewarded, either both material and nonmaterial. It can never be replaced with the word "dharmapria", although it happens to a man who has a wife of an employee in an agency (office). Likewise, the word career woman has the connotation of meaning that women who have certain professions need to be given a special mention because in general women in the public view is unprofessional and only play a role in the domestic sector so it is only worth working at home. Thus, if there are women who have a certain profession is given the title of career woman. It can never be replaced with the man word, even men have the same profession too as that of women.

Meanwhile, technological developments and the increasing demands of life in society lead to changes in some sectors of life. This resulted in a shift or even change the role of men and women in society. Not infrequently women who shifted its role from the domestic sector to the public sector. Similar to men, there is also a shift in the role towards the domestic sector. However, the vocabulary that accommodates the role of men in the domestic sector was never present or have not present yet. It is seen from the absence of the term father of the household, while for women there is the term housewife. Thus it is known that some words in Bahasa Indonesia represent gender inequality.

It can be understood through the theory of semantic derogation. Semantic derogation is the interpretation of words that refer to women getting negative meaning or getting sexual connotations (semantics means 'meaning' and derogation means 'making things seem inferior').

Semantic derogation in the Indonesian language represents the culture of Indonesian society that mostly adheres to patriarchal. Most of Indonesians adheres to the line of male descent (father). It is seen in a maledominated society. Men are perceived to have a higher position in society and subordinated women. These perceptions are expressed in the form of signs, one of 
them is language. It is in line with feminist communications theorist Julia Penelope, who has developed a critical theory of the universality of patriarchal discourse. Penelope is a linguist who holds that language is central to all human experience and society. How to understand it can be observed based on the elements of language created by the culture of the community. Therefore Penelope's theory deals with the patriarchal and oppressive nature of language for women [4].

Representation of Professional Markers (Labeling) of Women in Indonesian Vocabulary

In Bahasa Indonesia, there are also words that represent gender injustices in the form of professional women's markers compared to men. They are presented in Table 3.

Table 3: Women Representation as Professional Marker

\begin{tabular}{ccc}
\hline No general & Man & Woman \\
\hline 7 & mahasiswa & mahasiswa \\
8 & wartawan & wartawan \\
9 & sastrawan & sastrawan \\
10 & Polisi & Polisi Wanita \\
& Polisi & \\
\hline
\end{tabular}

Table 3 shows the use of terms in the profession and agency names for women are treated differently from men. The terms used to refer to professions such as "mahasiswa"(students), "wartawan" (journalists), "sastrawan" (writers), and "polisi" (police) are in fact more male so it is deemed necessary to provide a special marker if used for women being "polisiwanita"(female police), "wartawati" (women journalists). There is even a "sastrawati" (female author). On the other hand, it has never been used the terms "guru wanita" (female teacher), "female housekeeper", "female nurse", "nanny girl", essentially the profession / occupation tends to be related to the duties or roles of women in the domestic sector, that is care and take care of family (child).

The use of these terms represents gender inequality in Indonesian society so that it is represented in certain terms or vocabulary. Gender is a cultural concept that seeks to make distinctions in terms of the role, behavior, mentality and emotional characteristics between men and women developing in society [5]. Based on these limits, women are treated differently from men. Such treatment generally tends to differentiate between male and female roles. The role of women tends to be interpreted as a domestic role while men tend to the public sector. Therefore, if any woman entering public area, need to be given special marker because basically those roles are owned by man.

\section{CONCLUSION}

Based on the description above, it can be concluded that language and culture have a very close relationship. Language is a tool to express the culture of society. In contrast, culture is very influential on the development of a language. Therefore, in a patriarchal society, the tendency of gender inequality is also represented in the language used. It can be understood through the semantic derogation of the language.

\section{REFERENCES}

[1] Santoso, A. Dan Saryono, J. KonstruksiIdeologidalam Bahasa Perempuan. Laporan Hasil Penelitian tidak Dipublikasikan.

[2] Lucy, J.A. Language Diversity and Thought: A Reformulation of Linguistic Relativity hypothesis. Cambidge University Press.1992.

[3] Coates, J. Women, Man, and Language: A Socio linguistic Account of Sex Differences in Language. NewYork: Longman Inc. 1986.

[4] Ibrahim. A. S. Teori - teori Pengetahuan. Diktat Perkuliahan belum dipublikasikan.

[5] Jovovic. Jender dalam Perspektif Islam (online) diakses 26 Januari2012. 2008. 